\title{
7 \\ The material culture of caring and curing
}

\section{Valérie Leclercq and Veronique Deblon}

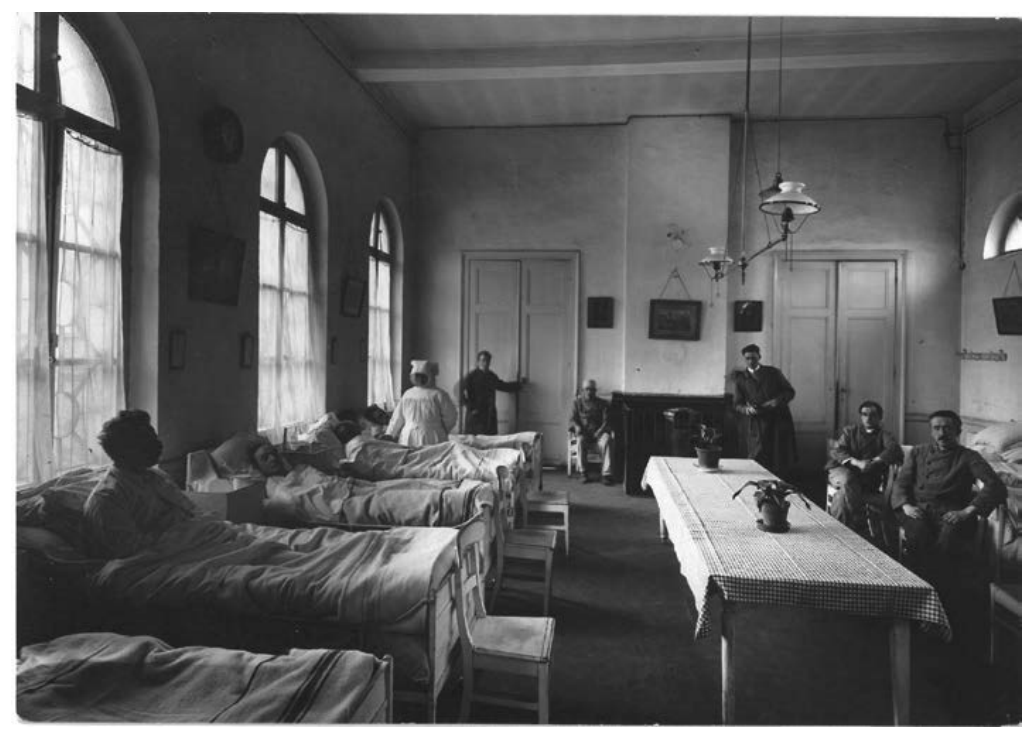

Figure 7.1 Photograph of a sick ward of the psychiatric facilities of the St-Jean Hospital in Brussels (1930).

Brussels, 1930. Bedridden patients, nurse and physician of the Hôpital St-Jean pose for a photograph (Figure 7.1). The picture presents a clean, well-ordered sick ward with frames hanging on the walls, beds, chairs and bedside tables. A piece of furniture as seemingly inconsequential as a bedside table can tell us a lot about the historic reality of such institutions. Bedside tables, just as their adjoining beds or chairs, were elements of comfort. They delineated an intimate, individual space that, even in its humble narrowness, 
not everyone could afford on the outside. In the drawers or on the tabletop, patients kept the few precious possessions that made them feel themselves: purses, administrative documents, but also small objects and images of sentimental value. Pieces of food (to be eaten, sold or slyly handed over to visiting family members) or pleasurable items such as cigarettes, pipes and alcohol also frequently found their way into the table drawers, in defiance of hospital rules. But if bedside tables allowed patients to retain some degree of joy and privacy in everyday ward life, they were also vulnerable to institutional intrusion. To curtail food trafficking, for instance, nuns and hospital wardens were often free to check the content of the tables whenever they pleased and to punish patients found at fault. ${ }^{1}$ This invasion was all the more brutal because often the items stored in their bedside tables were all that patients had, the only material extension of themselves authorised in the spacious wards. Patients had no wardrobes or lockers. They wore uniform. Their civilian clothes had been disinfected and stored away in hospital cloakrooms.

As shown here, the tension between individual dynamics and institutional control that characterised the situation of public hospital patients in interwar Belgium is all there, contained in this object sitting at the side of patient beds. Looking at it closer gives us a glimpse of what it meant to be treated in a hospital; and it tells us what was believed - by hospital administrators and the larger society - to be a poor patient's rights, needs and duties in the early twentieth century.

Narratives of teleological progress and of social control have for a long time dominated the analytical discourse of medical historians. Since the 2000s, these narratives have been challenged through the consideration of the material aspects of medical culture and the ways that these aspects tie to the complex ideological, social and economic organisation of society. This 'material turn' in the history of medicine - and in history in general - set out to reconstruct what anthropologist Arjun Appadurai termed 'the social lives' of objects. ${ }^{2}$ It surmises that artefacts (objects made or modified by humans) are 'historical events' that, like other historical events, do not 'just happen' but have a social history and are the product of multiple causes. ${ }^{3}$ In addition to their intended function, artefacts reflect 'directly or indirectly, the beliefs of the individuals who commissioned, 
fabricated, purchased, or used them and, by extension, the beliefs of the larger society'. ${ }^{4}$ The case of the bedside tables exemplifies how material culture can add layers and nuance to the history of medical institutions. The ways pieces of furniture, domestic objects, scientific instruments and architectural environments are built, used and adapted give us insight on everyday practices detached from the text of the rules and laws that regulated them. They also often engage a rich array of historical actors - patients, nurses, servants or other medical professionals - who have often been overlooked by traditional historical narratives. Complicating the history of institutional social control, recent material studies have, for instance, highlighted the 'domestic ideology' prevalent in nineteenth-century hospitals, pushing the idea that institutions (and society as a whole) should be modelled after middle-class home life and mirror family hierarchy. ${ }^{5}$ To study material culture also means to learn, as historians, to interpret the absence of objects as well as their presence. ${ }^{6}$

In Belgian medical historiography, material culture has only recently turned up on historians' radar. Previously, studies of the material aspects of medicine in Belgium have mostly focused on two areas: hospital architecture and museum collections (on anatomical museums and health exhibits, see Chapter 9, pp. 326-31). ${ }^{7}$ Hospitals in particular have received considerable attention, especially after the creation of the Société Belge d'histoire des hôpitaux/ Belgische Vereniging voor de Geschiedenis van de Hospitalen in 1963, but the resulting studies mostly focused on the history of individual institutions. ${ }^{8}$ Benoît Majerus and Sophie Richelle were among the first to explicitly approach their subject through the lens of material culture. Both looked at spaces and artefacts to recreate a poignant history of twentieth-century psychiatric hospitals and nineteenth-century nursing homes. ${ }^{9}$

Building from the existing historiography, this chapter will stay mostly in the institutional space of hospitals and asylums but will attempt to move beyond the study of architectural design. It will shed light on the ways the different materiality levels of the hospital - built environment, spatial organisation, artefacts - reflected ideas of cure and care, and can offer glimpses of past healthcare practices. Hospital design evolved in conjunction with scientific development, although it has continuously been subjected to 
other influences too, be they social, economic, religious or other. Historian Annmarie Adams showed that medical spaces, in addition to materialising medical theories, were also 'produced' by all social groups partaking in the everyday life of the institution (from patients, to caregivers and visitors). ${ }^{10}$

The material and architectural history of hospitals in Belgium has been heavily shaped by wider trends in hospital design and international architectural theories that were themselves informed by scientific progress and socio-economic changes in the Western world. Throughout the nineteenth and twentieth centuries, Belgian architects and physicians travelled out of the country to study the features of foreign institutions and imported new design models from abroad. What specificities, then, could be ascribed to Belgian healthcare institutions? Local context is key here, as prevailing theories on design could rarely be adopted without adjustments to in situ conditions. The persistent and imposing presence of religious congregations in the Belgian healthcare system, for instance, had a huge impact on hospital organisation in the country. Belgian hospital material culture points to the interconnectedness of care and cure, the tensions between freedom and control, and makes obvious the different meanings medical professionals and Catholic caregivers assigned to these concepts. ${ }^{11}$ This chapter will raise further questions about domesticity, privacy and hygiene in connection to institutional medicine, and explore the local, practical solutions found to address these issues.

The first section of this chapter will focus on the topic and practices of good ventilation, a central concern in the management of nineteenth-century medical institutions. Next, the ideology of domesticity told through the materiality of hospitals and asylums will be discussed. We will then go on to observe how the domestic ideal came to be supplanted by a new imperative of cleanliness that impacted hospital architecture, environment and furniture. However, the crusade against germs and the development of new scientific technologies did not alone shape nineteenth-century medicine. Hospital design and organisation also depended on moral and social norms, materialised through physical segregation and religious symbols. Finally, the emergence of the block hospital marked a turn in modern medicine; hospitals evolved to answer the social transformations of the twentieth century and new healthcare needs. 
The last section of the chapter will explore the businesslike management style of these new institutions and the impact it had on their design.

\section{Hospital organisation}

Up until the nineteenth century, care for the ill and destitute in the southern Netherlands was in the hands of Catholic congregations. Daily life in the hospital partly replicated the strict daily structures of convent life and hospital architecture mimicked religious buildings. For example, the medieval Bijloke Hospital in Ghent was modelled after its adjacent Gothic convent. After the French Revolution and the annexation of the southern Netherlands to France, healthcare was radically reformed and charitable establishments were placed under the supervision of local governments. In municipalities with a hospital, a local board on civil hospitals was in charge of public medical care (see Chapter 6, pp. 208-9). ${ }^{12}$ In the years following the French reorganisation, members of Catholic congregations returned to the hospitals and hospices, where they stayed active as nursing personnel until the mid twentieth century. As such, the hospital functioned as more than just a place of cure. Hospital work was part of the charitable and spiritual mission of religious congregations (see Chapter 2, pp. 68-75), while the interest of the state in taking over healthcare lay partly in the safeguard of public health and social order. ${ }^{13}$

In the early nineteenth century, old hospitals proved insufficient to provide medical therapy and failed to prevent contagion. ${ }^{14}$ One of their substantial drawbacks was their odour. Bad hospital smells not only determined visitors' negative view of the institution - which at the time was exclusively dedicated to the care of the poor ${ }^{15}$ - but these scents were also seen as an active threat to patients' health. The medical community identified foul odours, or miasma, as a cause of infection; putrid odours were associated with the dangers of contagious disease and epidemics. ${ }^{16}$ The fear of miasmic infection instigated medical professionals to reorganise hospitals and eliminate as much as possible the contagious odours of disease.

The search for a design that allowed air circulation, space and light led to the introduction of the pavilion plan. The use of 
pavilions (or long 'blocks' isolated from each other) resulted in the installation of unconnected sick wards, with enough space to separate patients from each other. High windows flooded the ward with natural light and enabled good ventilation. In both psychiatry and general healthcare, the idea that architecture itself was curative gained traction. Nineteenth-century physicians became actively invested in hospital planning. The Ghent psychiatrist avant la lettre Joseph Guislain advocated for medical professionals to serve as 'the architect's guide'. ${ }^{17} \mathrm{~A}$ well-organised hospital or hospice was not only designed to facilitate air circulation, but also to make possible the classification and segregation of patients according to their type of disease, gender or social status. Discipline, order and the discrimination of diseases, were thought to prevent the perpetuation of ill health and contribute to the healing process.

In Brussels, the St-Jean Hospital (1843) was known as Belgium's first pavilion construction. Its architect, Henri-François Partoes, was influenced by the latest standards in hospital design and had researched the organisation of several foreign facilities during study trips to Paris, Lyon and Plymouth. ${ }^{18}$ Although the very first English and French pavilion hospitals dated back from the late eighteenth century, ${ }^{19}$ pavilion construction only gained popularity in the nineteenth century. The St-Jean Hospital consisted of nine pavilions, connected by a two-storey covered gallery, where some patients took their walks. The design included separate floors for men and women and allowed segregation between contagious patients, patients with fevers and injured patients. ${ }^{20}$

Hospital style and appearance also came under increasing discussion. More and more voices turned against overly aesthetic hospital architecture. The surgeon André Uytterhoeven defended St-Jean's sober neoclassical style, stating that 'splendid ornamentation only adds to the cost [of the hospital], and does nothing to achieve its sanitary goal'. ${ }^{21}$ In the second half of the nineteenth century, functional buildings should be prioritised. This was also the opinion of the Superior Health Council (Conseil supérieur de la santé), a commission of non-medical administrators founded in 1849 to supervise city planning and the construction of public buildings (see Chapter 4, pp. 144-5). Compelled by the poor hygienic circumstances of Belgian institutions, the council created national guidelines concerning the location and spatial organisation 
of hospitals. ${ }^{22}$ They recommended the use of open galleries for the connection of hospital wards (instead of covered courtyards) and encouraged the use of pavilions. Although strict regulations for architects were imposed, once the council approved the plans of a hospital, there was no leverage to ensure the rules were actually followed. ${ }^{23}$ Architects and administrators therefore retained some autonomy, even enjoying some room for experimentation.

Frans Baeckelmans, the architect of the Antwerp hospital Stuyvenberg (1884), for instance, designed circular patient wards. ${ }^{24}$ The absence of corners was thought to prevent the accumulation of pathogens in typically dirty room areas. The sick ward radial plan also facilitated nursing supervision: caregivers could keep every patient in sight from their post at the centre of the cylindrical space. ${ }^{25}$ Although Stuyvenberg's plan met both the hygienic and surveillance concerns of the time, the Superior Health Council was reluctant to approve its experimental design. The council favoured instead the layout of the Mons civil hospital (1869), made of four semi-detached pavilions connected through a pedestrian bridge. ${ }^{26}$ The need to distract patients from their surroundings also preoccupied hospital administrators. The austere architectural style of the St-Jean Hospital was enlivened with flowerbeds and courtyard plants. ${ }^{27}$

Despite their modernity, nineteenth-century hospitals had an image problem. The indigent class perceived them as places where 'they [w]ere used for experiment, and after death ... for instruction'. ${ }^{28}$ Indeed, public hospitals allowed clinical research in their wards and the dissection of its non-paying population in their anatomical theatres (see Chapter 5, pp. 180-3). ${ }^{29}$ Due to their limited recovery rate, hospitals were often seen as places of last resort. However, some medical professionals believed that this perception could be improved by opting for the luxurious architecture some of their colleagues decried. Physician Constant Crommelinck, for instance, claimed that, although hospitals 'evoke repugnance among the poor', beautiful facilities would encourage the destitute not to postpone medical care. ${ }^{30}$ Inspired by foreign hospital architecture, physicians saw beautiful hospital architecture as a way to legitimise institutional healthcare in the eyes of the reluctant poor.

Hospitals' (luxurious) appearance manifested the benevolence of their patrons and founders. The choice of a particular architectural 
style could also express an institution's ideological ties. Architect Adolphe Pauli, in charge of Ghent's new Bijloke Hospital (186378), ${ }^{31}$ matched part of his eclectic design to the Gothic architecture of the medieval Bijloke convent ${ }^{32}$ and in doing so, highlighted the Catholic identity of the hospital; other neo-Roman elements echoed Ghent's nineteenth-century urban landscape and pointed to the hospital's link to the (liberal) city council.

\section{The domestic ideal: between home and institution}

When the new asylum in Ghent opened in 1857, the press praised it as a 'Byzantine palace' and stressed its material comfort. ${ }^{33}$ Its rich, eclectic architectural style answered to the bourgeois taste of the nineteenth century. As in most hospitals, the furniture and spatial organisation of sick wards were guided by the domestic ideals of the middle and upper class. For example, every patient had their own bed. Having one's own bed was a self-evident fact for the upper class, yet remained unusual in the homes of the destitute. Extreme deprivation was not uncommon in nineteenth-century Belgium. ${ }^{34}$ Crowded unsanitary housing, dampness and coldness were the unfortunate lot of many families, who usually lived in one- or two-room dwellings where all family members shared the same bed. The degree of material comfort and privacy enjoyed by institutional patients can only be judged in relation to this broader material context. In 1845, a visitor to the newly opened St-Jean Hospital particularly lauded the unexpected cosiness of the heating system in the galleries: 'by way of precaution, which resembles tenderness, they have conducted the hot air under the benches so the sick can sit without catching a cold'. ${ }^{35}$ The domestic ideal was further translated to the style of hospital furniture. Beds and bedside tables were painted to imitate wooden oak furniture. ${ }^{36}$ Many hospital beds had closable curtains that separated patients from the rest of the ward (Figure 7.2). Curtains around the bed were meant to turn the space of the bed into a 'personal refuge' for patients and shielded their agonies and (painful) treatments from other patients. ${ }^{37}$

Medical professionals further embraced the domestic ideal in the organisation of institutional care, as is evidenced by two competing 


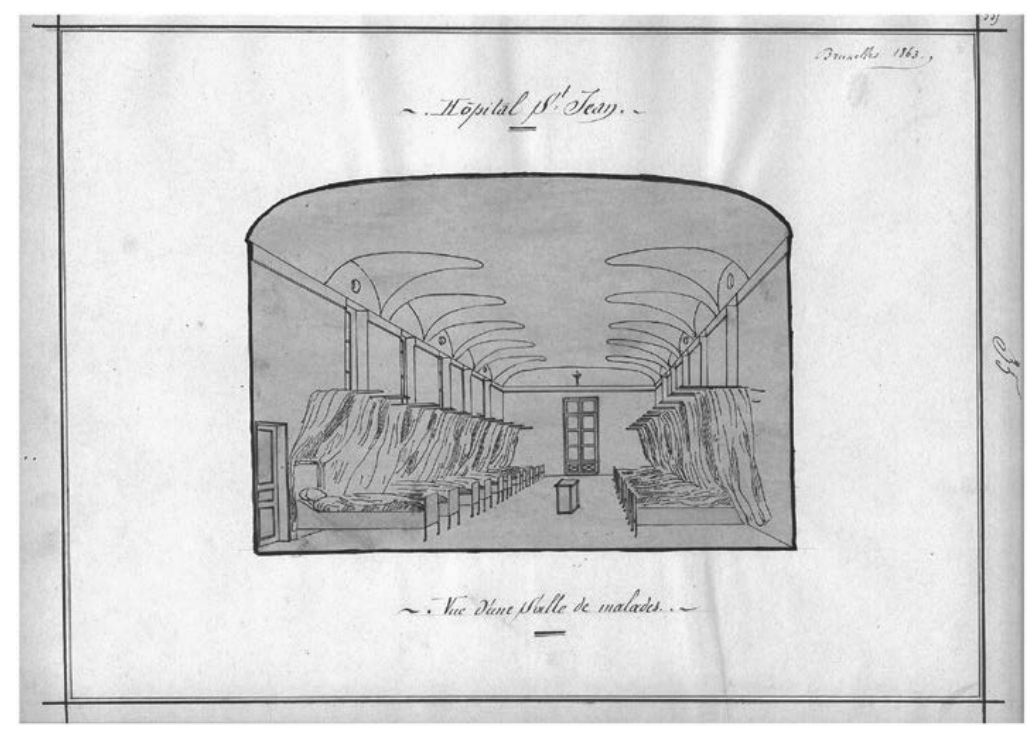

Figure 7.2 Vue d'une salle de malade (patient ward of the St-Jean Hospital in Brussels), painting on paper (1863).

regimes that structured Belgian psychiatric care: asylum care and community care. In Gheel, a village in the rural Campine region, the mentally ill were placed with local foster families. There, they enjoyed a relative amount of freedom and were allowed to move around freely in the village. In exchange for their care, lodgers helped out with household chores or performed agricultural labour. ${ }^{38}$ In general, family care in Gheel was lauded for its philanthropic spirit, yet some medical professionals dismissed it and proclaimed asylums the only suitable place for psychiatric treatment (see Chapter 8, pp. 294-8).

The nineteenth century saw the rise of 'moral treatment', the first institutional therapeutic approach to madness. Moral treatment was based on the idea that the mentally ill could be cured if they were talked to, reasoned with and if a strict set of moral beliefs and a routine of order and labour were imposed on them. Chains and other forms of restraint were avoided as much as possible. Architecture 
was crucial in the reform of the nineteenth-century psychiatric landscape and proved an important tool to the propagation of moral treatment. Joseph Guislain, one of Belgium's first advocates of moral treatment, campaigned for new, purpose-built pavilion asylums and translated his medical ideas into elaborate architectural plans. The ideal asylum was situated in a rural area - far away from the pathogenic influence of the industrial city. Guislain called the new institution Maison d'hommes aliénés, a 'home' for alienated men. Mechanisms of confinement were concealed as much as possible from patients and the public. Windows were enhanced with 'decorative bars', which were aesthetically pleasing but still prevented escape. The wall around the domain was designed to recall the convent wall rather than the prison wall and it was camouflaged with a hedge..$^{39}$ All these manoeuvres were intended to distract patients from their confinement. Nineteenth-century asylum architecture in general aimed to create a feeling of domesticity, ${ }^{40}$ while in Belgium the institutional orientation towards domesticity also allowed it to compete with community care. ${ }^{41}$

Despite the fierce medical critique, the public opinion remained favourable towards community care or family treatment. To the government, it was much cheaper to lodge the (insane) destitute with families than to provide (often lifelong) institutional care. Yet, physicians and government administrators agreed on the necessity of reforming Gheel's community care and ordered the installation of an 'infirmary' or sick bay. Guislain's influence on the reform of the colony was accordingly brought to bear through the construction of this infirmary.

Controlling mechanisms similar to those of the Ghent asylum were employed. For example, patients were classified in different categories (from 'tranquil' to 'agitated') and accordingly housed in different parts of the village; similar windows with decorative bars were installed. The infirmary served as a disciplinary space where patients were observed, isolated and received therapy. The colony's director, Jean Bulckens, explained to his peers: 'the patients are not free, but at least they have the illusion of freedom'. ${ }^{42}$ After the reform, the enthusiasm grew for family care and the organisational model of the Gheel colony was exported to several foreign countries such as France, Germany and even Japan. ${ }^{43}$ 


\section{Medicine after the Pastorian revolution and its impact on hospital architecture}

Up to the 1930s, the pavilion plan remained the norm for hospital design in Belgium. It was still strongly favoured by the Superior Health Council in its 1928 instructional leaflet. ${ }^{44}$ The history of Belgian hospitals in the wake of the 'Pastorian revolution' is thus not that of a radical transformation of architectural spaces. What we observe instead is the constant upgrading and readjustment of structures still firmly rooted in nineteenth-century hygienist principles. While elements such as ventilation and light remained central to the reasoning of hospital building experts, the new leitmotiv of 'decentralisation' encouraged the gradual division and isolation of hospital units. Furthermore, the application of new scientific knowledge and inclusion of new medical technologies gave shape to a material environment more and more unique to the hospital. To understand the slow permutation of the pavilion system, we must distinguish between various interconnected areas of medical development. Each had an impact on hospital design and organisation.

First, the evolution of medical knowledge itself was decisive. The work of Pasteur, Lister and Koch in the second half of the nineteenth century redefined our understanding of disease. No longer caused by an undetermined miasmic manifestation, it was now revealed to be the product of a variety of microorganisms. The germ theory led to new hygienic practices. Dust, rather than elusive miasmas, came to be seen as the new pathogenic force to oppose. ${ }^{45}$ From then on, hospital cleanliness would rely on the creation of easily washable and disinfectable environments. Architects still wanted their hospitals flooded with natural light too, for sunlight not only allowed hospital cleaners to better spot dusty areas but also 'exert[ed] a sterilising influence on bacteria'. ${ }^{46}$

For the most part, the pavilion model seemed to satisfactorily accommodate the hygienic ideas and practices derived from the bacterial theory. It also allowed the containment of different germ types (i.e. groups of patients) in separate pavilions. The principle of 'decentralisation' adopted by most hospital administrations at the time encouraged, for sanitary reasons, the strict separation of departments, each forming their own independent unit. ${ }^{47}$ In Brussels 
and its surrounding municipalities, the Military Hospital (1888), the Brugmann Hospital (1923), including its Psychiatric Institute (1931), or the Reine Élisabeth Hospital (1930) were all comprised of a large set of ground-floor pavilions. ${ }^{48}$

Between 1880 and 1930, the traditional two-department structure of the earlier healthcare institutions (medicine and surgery) was also confronted with the gradual emergence of new medical specialties such as ophthalmology, otorhinolaryngology, gynaecology, psychiatry, urology, etc. As medical knowledge and teaching grew more specialised, physicians demanded that distinctive spaces be created within the hospital to accommodate the new specialties. In existing hospitals, this often led to the reorganisation of the internal layout of the buildings. But administrators and physicians often struggled to maintain the coherence and practicability of their hospital's original design and to provide clear separations between the various departments. ${ }^{49}$ The construction of new buildings was far easier.

Luckily, the pavilion system allowed for a convenient expansion of an institution's housing capacity. The last decades of the nineteenth century and the early decades of the twentieth thus saw an impressive multiplication of pavilions on hospital grounds. As a late example of pavilion construction, the Brugmann Hospital perfectly illustrates the expansive logic of a system that became increasingly more costly over time: designed by art nouveau architect Victor Horta, it consisted of no fewer than sixteen different departments, each comprising of one to five individual pavilions. Its myriad of buildings sprawled out across a twenty-hectare park located in one of the peripheral neighbourhoods of the capital. ${ }^{50}$ The ever-growing number of individual pavilions not only demanded the purchase of bigger and bigger hospital lots, but also meant the pricey duplication, for each edifice, of a series of utilitarian spaces (entrance hall, kitchen, consultation areas) and building features (roof, cellars, walls). This phenomenon, of course, was affecting hospital construction everywhere. In Lyon, France, the colossal EdouardHerriot Hospital had twenty-three departments located in twenty different pavilions. By the time the hospital was ready to open its doors to the public in 1933, it had cost 206 million francs instead of the budgeted 13 million. ${ }^{51}$

The development of the medical profession and the exponential number of medical students also increased the need for teaching 
spaces within public or university hospitals. Clinical lessons moved from the patient wards to makeshift classrooms, to auditoria. Technological innovation demanded the further moulding of hospital space to accommodate new tools, therapeutic procedures and often cumbersome - equipment (i.e. X-rays, blood and urine testing laboratories, hydro- or electrotherapy, etc.), sometimes even necessitating the creation of whole new departments.

\section{Germs and easily washable surfaces: a new cleanliness}

The material environment of hospital and asylum patients changed drastically after the 'bacterial revolution'. It soon came to be defined by three distinct characteristics: smoothness, imperviousness and sparseness. Because Belgian physicians imported antisepsis methods and theories at least a decade later than their French or British counterparts, ${ }^{52}$ that transformation mostly began in the 1890 s and early 1900s. The discovery of germs demanded a redefinition of what constituted a salubrious environment.

First, the walls and floors of the patient wards could no longer be made out of absorbent, dust-catching or friable material. Walls, often the object of crude whitewashing in the past, ${ }^{53}$ were now stripped of their wooden panelling or mouldings, covered with cement, enamel, stucco or earthenware tiles and received multiple layers of light-coloured paint and varnish. ${ }^{54}$ The cheap and soft pinewood floors of older hospitals, which were dry scrubbed with coffee grounds or moist sand, ${ }^{55}$ were also discouraged. Preference was given to watertight and seamless materials. ${ }^{56}$ The Superior Health Council and the Brussels Hospital Administration favoured oak or 'bituminous wood' floors coated with specific waxes. ${ }^{57} \mathrm{In}$ the early 1900s, the new public hospital in Charleroi opted for torgament imported from Leipzig: a compressed mixture of magnesium chloride, sawdust, resin and cement. ${ }^{58}$ Floors had to withstand repeated washing with disinfectant solutions. In 1928, the Superior Health Council specifically recommended that pieces of furniture be 'constructed so that they may be washed and disinfected without deteriorating', preferably in iron or (treated) wood. ${ }^{59}$ In a report to the city authorities dating from 1903, physicians from the Brussels public hospitals explained the measures they were about to take 
to ensure a safer ward environment: 'Furniture will be reduced to what is strictly necessary (beds, chairs, benches, night tables, fireplaces, large tables, spittoons, washbasins, mirrors) ... Most cabinets can be placed in separate rooms. The carpets, curtains, and table-cloths which you can still find in some [places] will be done away with. ${ }^{60}$ Indeed, heavy fabrics caught dust and germs easily. So did non-human organisms, which also had to be removed from the patients' direct environment. New regulations forbade keeping 'plants or live animals which at the present time ... are reintegrated into the rooms [after disinfection], thus rendering incomplete and illusory the results of the operation'. ${ }^{61}$ In another section, the report continued: 'whenever possible, wooden objects will be gradually replaced by other metal and glass objects' ${ }^{62}$

Without the immediacy demanded by the management of surgical environments, with lesser financial means and a huge patient population to provide for, psychiatric institutions seemed to have been slower to meet the new standards of Pastorian hygiene. In the interwar period, some of the patient beds of the Beau-Vallon asylum, near the city of Namur, were still made of wood. ${ }^{63}$

All these changes partly prompted the 'modern' look and feel of the twentieth-century hospitals and, to a lesser extent, institutions for the insane. There were legitimate scientific imperatives behind the use of materials favoured by modernist architects, like glass, metal, stone, enamel or bricks. ${ }^{64}$ With the addition of new therapeutic, surgical and diagnostic equipment too, hospital environment acquired a new scientific character, setting it more distinctively apart from everyday domestic settings than ever.

\section{Wards and individual rooms}

Despite undergoing a triple process of medicalisation, technologisation and specialisation, which earned them a growing legitimacy as places of medical and surgical treatment, turn-of-the-century hospitals remained firmly anchored in the realm of moral and charitable care. Confinement and discipline still characterised a large part of their therapeutic approach and heavily defined their materiality. The judgement of poor hospital patients, just like that of asylum patients at the time, was often perceived as irrational and unlikely to 
lead to good decision making and better health. In many situations, it was thought that patients had to be protected from themselves.

Large wards remained central to the experience of a majority of hospital and asylum patients well into the twentieth century. They marked healthcare institutions as collective spaces and made discipline a managerial necessity. But the kind of discipline demanded by the open wards also had a moralising - and thus therapeutic effect. It commanded that patients behave appropriately towards each other and respect social hierarchy, that they assimilate the habits of good collective hygiene and contribute to the community by taking care of the communal space.

The size of that communal space decreased progressively. Whereas wards of twenty to twenty-five beds were still the norm in 1853, this ideal number decreased to 'no more than 20 beds' in $1911 .^{65}$ By the late 1920s, the Superior Health Council had decided that six or seven was the maximum number of patients a decent hospital ward should accommodate. In the small private Hôpital Français, located in Berchem Ste-Agathe, rooms had no more than nine beds. ${ }^{66}$ Opened a few years before, in 1923, the gigantic Brugmann Hospital favoured three different ward formats: eight, twelve or sixteen beds. ${ }^{67}$ When the Brugmann Psychiatric Institute opened in 1931, however, most of its wards still contained twenty-two beds. ${ }^{68}$ Indeed, psychiatric patients had to endure the reality of large dormitories for a longer time.

This does not mean that there were no individual rooms in nineteenth- and early twentieth-century Belgian hospitals. There were in fact many of them. They, however, served two very specific functions. Their first purpose was that of medical isolation. Some small individual rooms, usually located next to the wards, were set up to receive patients who had to be separated from the ward population for medical reasons: contagious, dying, delirious or malodorous patients, for instance. ${ }^{69}$ Another type of individual room provided for its part a means of social isolation. Usually built far from the wards, private rooms for 'paying patients' were a rare luxury reserved for a class of people that would not have tolerated being associated with the general population (see Chapter 6, pp. 220-4).

Since the law on public charity did not explicitly forbid it, the presence of middle-class patients in publicly funded hospitals had been accepted as customary. ${ }^{70}$ Few mid-nineteenth-century bourgeois, however, would have dreamt of setting foot in a hospital. But 
things slowly started to change at the turn of the twentieth century for two reasons. First, the development of hospital surgery, medical technology and scientific knowledge about diseases brought a new effectiveness and attractiveness to hospital medicine. Second, these same developments drove up the costs of private healthcare and made it more difficult for even the better-off to afford certain expensive treatments. From the 1880s on, Belgian public hospitals experienced an ever-growing demand from middle-class patients looking for more specialised and cheaper treatment options. ${ }^{71}$ This prompted most hospital administrations to seek ways to better integrate this 'new' lucrative population into their managerial outlook. In 1903, administrators of the small Turnhout Hospital decided to set up two three-bed rooms to accommodate its middle-class patients. ${ }^{72}$ In the municipal hospitals of Tournai and Charleroi, private patients got their own quarters in, respectively, 1891 and $1910 .^{73}$

\section{Social order and material segregation}

Cohabitation between the various social groups forced into the same restricted space was impacted by a fear not only of medical, but also of social contamination. Indeed, the therapeutic mission of hospitals called for the upholding of an environment that was not only medically but also socially and morally salubrious. Health could not be achieved without social and moral orderliness. The physical layout of hospitals and asylums sheds light on the views that physicians and administrators held on this sanitary-social order.

First of all, it was understood that patients had to be kept separated from the outside world. This required that both hospitals and asylums remained, to a certain degree, secluded spaces. It is no coincidence that, in official hospital and asylum jargon, patients leaving the premises without warning were said to have 'broken out'. Social segregation within the institutional space was also deemed essential to a healthy institutional order. Bourgeois and poor workers were kept separated in different buildings or parts of the buildings. In the Beau-Vallon asylum, better-off patients were welcomed from the mid 1920s on in the pavilions 'Charles' and 'Marie-José', where they enjoyed the privilege of individual rooms 
and a bourgeois interior that was set up with a reading room and paintings on the walls. ${ }^{74}$ To avoid social mixing, the Brussels public hospitals went as far as allowing patients to occupy private rooms based on their social status even when they could not pay for their hospital stay. ${ }^{75}$ Hospital and asylum architecture in the first half of the twentieth century continued to prevent interaction between female and male patients.

The prevention of moral contamination led, in addition, to complex marginalising processes of both spaces and patient groups within the hospital walls. The management of venereal patients perfectly illustrates this assertion. In earlier healthcare institutions, men and women with venereal diseases were often treated in the general wards. This was the case in the old public hospital in Liège, where syphilitic patients shared the same space as other patients. But in 1876, physicians of that hospital argued in favour of creating an isolated unit of six to eight beds dedicated to the exclusive treatment of female venereal patients. ${ }^{76}$ If this request could be ascribed to an early process of specialisation, it was also clearly motivated by the perceived necessity to seclude patients thought to be a corrupting influence on others 'because in the presence of young ladies, they [were] rude and [made] inappropriate comments'. ${ }^{77}$ It was commonly assumed at the time that female syphilitic patients were dissolute women. In the St-Pierre Hospital in Brussels, women and men with venereal afflictions had been treated in a specialised department since the mid nineteenth century. But additional 'moral' and material divisions were perpetuated within the department itself. 'Venereal women' who were registered as prostitutes by the police were not allowed in the proximity of other venereal patients and could only receive treatment in closed quarters from which they were forbidden to leave. It was often months before the head physician decided they were cured and agreed to their release. ${ }^{78}$ The 'prostitute quarters' were comprised of eighteen beds (then four, after 1904) and had bars on the windows. ${ }^{79}$ They also served as a disciplinary space for badly behaving women from the open syphilitic wards. In 1895, for instance, two female patients were demoted to the closed quarters after having been caught kissing each other in the yard.$^{80}$ But even further segregation was implementable; the quarters also had 'cachots' (cells) to isolate disobeying prostitutes. ${ }^{81}$ From the general ward, to the venereal ward, to the prostitute quarters, to 
the cell: this trajectory was that of a gradual social regression built into the hospital architecture itself. The closed quarters remained a feature of St-Pierre until the hospital's destruction in 1929.

\section{Chapels, statues and cross pendants: religious discipline, religious healing}

Members of hospital and asylum religious personnel helped enforce the many moral and social segregations of the institutional space and were particularly attentive in preventing illicit contacts between men and women. ${ }^{82}$ But their religion, too, reinforced the institutional order with its own form of moral discipline.

In Catholic hospitals, hospices and asylums, the centrality and sometimes striking luxury ${ }^{83}$ of the chapel was a constant reminder of the desirability of spiritual life and of a believer's obligations towards God, his brethren and himself. The call to mass marked the rhythm of institutional life. In the old Onze-Lieve-Vrouw Hospital in Oudenaarde, an abundant number of statues of Christ, of the Virgin Mary and of the saints adorned the walls of each ward (Figure 7.3); they were supplemented with a ceiling-high

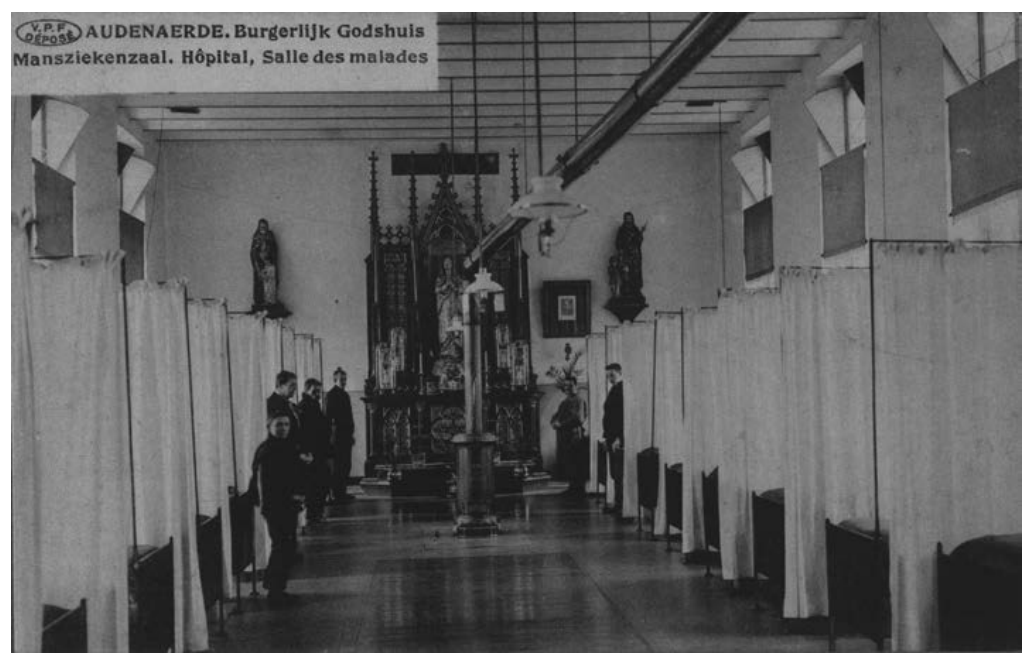

Figure 7.3 Postcard of a sick ward of a hospital in Oudenaarde (1915). 
wooden altar at one end of the room. ${ }^{84}$ Catholic statuary invited the patients to emulate the examples of the holy figures offered to their view and, in their time of suffering, to trustfully submit to divine authority, like they trustfully submitted to their physician's orders. In the Sisters of Charity-run Beau-Vallon asylum, the chapel and cemetery ensured the religious autonomy of the institution and provided a religious framework for the life of its residents, up to their death. ${ }^{85}$

At the turn of the twentieth century, a substantial proportion of hospitals, and almost all psychiatric institutions, remained in the hands of Catholic congregations. ${ }^{86}$ For this reason, the secularisation process of the Belgian healthcare system had nowhere near the virulence and impact it had, in the same period, in a neighbouring Catholic country like France. Public hospitals, especially in liberal or socialist municipalities, did, however, experience tensions between their Catholic staff and lay administrations. But the prolonged need for 'cheap' religious nursing personnel and the extremely high percentage of public hospital patients still identifying as Catholic ensured the continued presence of religion in the everyday life of non-confessional institutions too. ${ }^{87}$ That presence materialised around patients in many ways, although, much more than in private Catholic institutions, it had the distinct characteristic of being pushed from the bottom up. The installation of a centrally located chapel and of sparse Christian and Marian statues was usually conceded and engineered by lay hospital administrations themselves. ${ }^{88}$ But the religious marking of public hospitals was as manifest in the candles carried by Catholic sisters, in the clothes they wore and in the holy water they threw on dying patients, sometimes in violation of hospital regulations. In the St-Jean Hospital, rosaries, prayer books and leaflets distributed by the hospital chaplains, similarly, encouraged religious contemplation and discipline. ${ }^{89}$ As for patients, a portion of them - mostly non- (or non-practising) Catholics - were reluctant to pray, to go to mass and confession or to receive the Last Rites. But many others were eager to take part in spiritual life. In 1886, female patients from the public St-Pierre Hospital in Brussels petitioned to get a Christ on the cross for one of the open venereal wards: 'You must understand, Sir, that it is sad for us to be without Christ because, in the room we left, we had one', they 
wrote to the Superintendent, who quickly sought to satisfy their wish. ${ }^{90}$ In public nursing homes in Brussels, residents often hung their own crucifixes in their individual rooms or had statues of the Virgin Mary on their bedside tables. ${ }^{91}$ In the public wards of the capital, patients wore scapulars of the blessed Virgin on their chests or cross pendants. ${ }^{92}$

Religious administrators, Catholic sisters, priests, servants and patients, through their combined efforts, contributed to sustain a material and visual environment connected to the divine. In her study of the Catholic sickroom, Carmen Mangion argues that 'a spiritual atmosphere [was] considered integral to Catholic understanding of a healing environment'. ${ }^{93}$ In both religious and lay public institutions, the chapel and the consecrated objects marking out the lived-in space had thus both a spiritual and therapeutic function; they were a link to God and tools of a religious discipline that aimed to heal, if not the body, at least the soul. They invited patients to subscribe to a Catholic moral regimen centred on obedience, bodily discipline, prayer and sacramental events. And despite their principled opposition to a religiously suffused medicine, lay hospital administrators were not above harnessing Catholic moral authoritarianism for their own purpose of social discipline.

\section{The block hospital: towards the modern institution of the twentieth century}

In the late interwar period, Belgian hospitals underwent a total reconfiguration of their physical form. A new solution for large urban hospitals engaged in acute care, teaching and research came with the advent of the 'block hospital', now arranged vertically rather than horizontally. This architectural revolution had started decades earlier in the United States and the United Kingdom, where multistorey hospital towers were often installed in upscale commercial districts. Belgium's hospital landscape, however, changed slowly. The Superior Health Council originally disapproved of this new building type. Its eventual institutionalisation was the product of a determined Belgian medical profession and powerful foreign influences. ${ }^{94}$ 
The first 'block' hospital in Belgium was the new St-Pierre Hospital. In 1919 and 1920, professors from the Université Libre de Bruxelles sought the help of the Rockefeller Foundation to erect a new university hospital in the capital. Among them was Antoine Depage, who had favourably impressed the Foundation during the First World War with the setting up of his Hôpital de l'Océan on the Belgian coast. ${ }^{95}$ The conditions imposed by the Rockefeller Foundation led to the development of a common project between the Foundation, the university and the local city government. The project focused mainly on the total rebuilding of the old St-Pierre Hospital in the heart of Brussels's working-class neighbourhood Les Marolles. ${ }^{96}$ The hope was to create an institution 'completely modern in spirit, in the supports and facilities at its disposal, and in the opportunities it offers', as well as to 'position Brussels as a centre of medical progress'. ${ }^{97}$ Inspiration for the building and managing of the new hospital was gathered from a long study trip to various establishments in the United States, Canada and the United Kingdom. The president of the Rockefeller Foundation also insisted that the hospital director and nurse in charge of the records do their training overseas. ${ }^{98}$

When it opened in 1935, the new St-Pierre Hospital had a bed capacity of 610 . Its central building spread over seven floors (including the ground floor and the basement floor). It housed thirteen outpatient clinics, two large departments of general medicine and surgery on the second and third floors, four specialised departments and a maternity ward. All were equipped with laboratories, classrooms and operating rooms. The building also housed a large admission area, an emergency room (ER), an X-ray department, a social services department and a rooftop solarium. ${ }^{99}$ Many new medical institutions such as the Jules Bordet Institute in Brussels (1939) or the University Hospital of Ghent (1937-70) followed this lead and adopted the new plan (Figure 7.4).

There were, of course, scientific reasons behind these radical transformations in hospital layout. Hygienic standards and practices shifted as the understanding of infection progressed. The dangers of contagious diseases were soon mitigated by the marketing of penicillin and other antibiotics. These scientific insights made the hygienic precautions of the pavilion hospital redundant: its wards appeared too vast, its ceilings too high, its buildings too distant from each other and its height needlessly restricted. ${ }^{100}$ Up-to-date disinfection methods and a well-thought-out ventilation system were deemed 


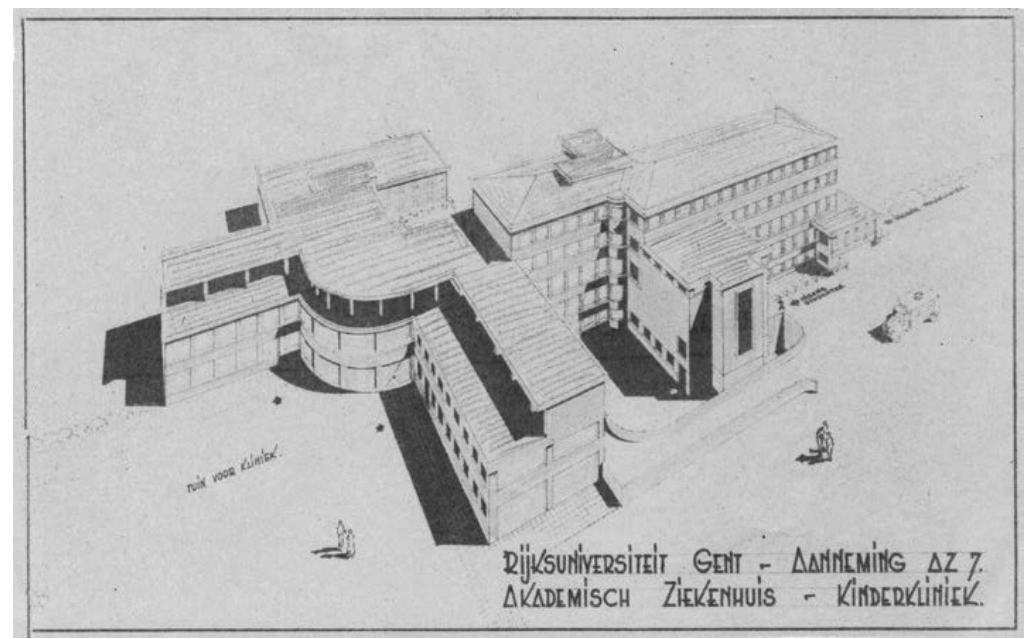

Figure 7.4 Drawing of the children's hospital (academic hospital of Ghent).

enough to ensure optimal hygiene. ${ }^{101}$ Furthermore, makeshift army hospitals assembled during the First World War had proven that buildings made out of lighter materials such as wooden boards and concrete plates were no hindrance to safe medical practices. ${ }^{102}$

Other aspects of changing medical thinking and practices played into these transformations of hospital architecture. The construction of 'compact' hospitals signalled a new will, among physicians, administrators and architects, to reduce the physical and psychological distances that prevailed in the former pavilion institutions. The centralisation process initiated by monolithic hospitals meant the decompartmentalisation of hospital departments and new possibilities for collaboration between physicians. Hospital administrators wished for a more collaborative and unified medicine, mostly to mitigate the ever-growing division of medical knowledge into specialised fields. ${ }^{103}$ The re-centralisation of hospital functions further allowed to reduce construction costs and to maximise the use of space. It also facilitated the circulation of patients and nurses within the hospital.

The nursing staff in particular benefited from the new vertical hospital, which reduced the running around required by service activity. Professional nurses felt that they should be taken into consideration by hospital planners because, more than any hospital professionals, 
'they $\mathrm{kn}[\mathrm{e}] \mathrm{w}$ the distances to be travelled and [appreciated] very well the difference between the twenty or the hundred steps that one [had] to take to get a glass of water for a patient'. ${ }^{104}$ There was no question that the layout of hospital buildings impacted on both the quality and the quantity of the work done by the nurses.

The transformation of the hospital was further influenced by developments outside of the medical realm. In the reconstruction period after the First World War and the later crisis period of the 1930s, economic imperatives, more than anything, drove the decision making of public authorities. The Superior Health Council encouraged the buying of local materials to boost the national economy. The use of Belgian concrete in interwar hospital construction, for instance, was in large measure induced by the soaring price of Belgian bricks (due to a high demand) and a protectionist duty to forego importing foreign construction materials. ${ }^{105}$ In the 1930s, most Belgian hospital professionals came to agree on the economic superiority of block hospitals over pavilion institutions. Compact hospitals occupied smaller ground surface; not only could they be built with cheaper materials and less labour, but they also required less equipment, less maintenance work, less surveillance and less nursing and domestic personnel. They also spared hospital architects the temptation of luxurious facades and expansive architectural details. Indeed, block hospitals were characterised by a new minimalism and functionalism that were in line with the new modernist trend in architecture, a movement lead in Belgium by Gaston Brunfaut and Henry Vandevelde. ${ }^{106}$ General technological developments such as the democratisation of electricity, the breakthrough of elevator technology and improvements in construction techniques also contributed to the achievements of modernist architects in the field of medical construction.

\section{Social transformation}

A lot of material aspects of the changing layouts of twentieth-century hospitals can be linked to major social evolutions in Belgian society, most of all, to the relaxing of class distinctions. In the mid 1940s, middle- and upper-class patients were much more comfortable with seeking medical treatment outside of their homes, in private clinics, 
sanatoria or specialised medical centres. But hospitals were still specifically seen as places of care for the 'economically weak'. ${ }^{107}$ The perceived need to control and discipline the indigent hospital population, and to separate it from better-off patients, thus continued to inform hospital architecture. In the 1930s, the novel use of glass partitions allowed the nursing and medical staff to keep an eye on contagious or gravely ill individuals as much as it allowed them to monitor the inside of patient wards. In the new St-Pierre Hospital, partially glazed partition panels set up inside the patient dormitories to separate groups of beds gave the nurse continual visual access to the patients. ${ }^{108}$ At the same time, hospital planners continued to integrate areas for paying patients into the design of public medical facilities: St-Pierre housed a thirty-three-bed wing for private patients on its fourth floor. ${ }^{109}$

These disciplinarian concerns decreased in intensity in the second half of the twentieth century as Belgium underwent a certain degree of social levelling. Just as in most Western societies, a series of intertwined processes impacted the social landscape of the country: the multiplication of jobs in the public and service sectors, the expansion of the middle class, universal suffrage and a democratised access to comfort and domestic technology. ${ }^{110}$ In 1944, the decree law of 28 December introduced the national social security system for all salaried workers and offered roughly 60 per cent of the Belgian population the benefit of compulsory 'sickness-invalidity' insurance. ${ }^{111}$ As a result, insured workers and paying patients replaced the destitute sick in the country's hospitals. In 1890, for instance, 90 per cent of the patient population of the Stuyvenberg Hospital in Antwerp was assisted by the local public welfare bureau. In 1960, this proportion was only 5 per cent. ${ }^{112}$ In 1963, the first 'law on hospitals' guaranteed free hospital care to all social security beneficiaries. ${ }^{113}$ By 1969 compulsory healthcare insurance was expanded to the entire population and hospitals were well on their way to become the shared referent that they are today (see Chapter 6, pp. 224-9).

As a result, the medical profession and society in general moved slowly towards a view of hospital patients as clients and no longer as recipients of public charity. In Belgian professional literature, discourses emphasising hospitals as providers of services and comparing them to hotels can be traced back at least to the 1930 s. ${ }^{114}$ But this perception grew in importance in the second half of the 
twentieth century. The conversion of patients into consumers parallelled the advent of the 'tower hospital' with its built-in shops and cafeterias. Concretely, the social levelling of the hospital population and a new respect for patient privacy led to the gradual elimination of large wards. ${ }^{115}$ Hospital patient populations were no longer to be confined and disciplined.

Of course, confinement was much more difficult to do away with in the context of psychiatric architecture. But Belgian psychiatry, despite its heavily institutionalised nature and the limited impact of the local anti-psychiatric movement, underwent a process of deinstitutionalisation not entirely dissimilar to that experienced by other Western countries. If the Brugmann Institute, in the 1930s, had the first open wards of the country, the 1970s and 1980s saw the progressive opening of the whole establishment. During the latter decades, the institute's two large pavilions were replaced by smaller buildings structured around rows of individual rooms. In the same period, the Beau-Vallon asylum opened several outside residential facilities. This was a decade before the launch of the 1991 national plan to encourage the development of 'MSP' (psychiatric care houses) and 'IHP' (protected homes initiatives). ${ }^{116}$

The religious marking of the hospital and asylum environment also waned progressively. This was as much the result of the deChristianisation of the Belgian population as that of the gradual replacement of religious personnel with lay trained professionals. In Antwerp, the last Catholic sisters left the Stuyvenberg Hospital in 1977. ${ }^{117}$ As soon as the early 1930s, hospital chapels found themselves relegated to the margins of hospital locations, usually above the morgue. ${ }^{118}$ Crosses and religious statues were now removed from sight too. These were all signs of the internal social metamorphosis of Belgian hospitals (i.e. of their transformation from charitable institutions for the poor to the technological and scientific centres that they are today).

\section{Centralised businesses: hospitals at the end of the twentieth century}

Purpose-built high-rise hospitals proved instrumental in the evolution of healthcare from a philanthropic, religious endeavour to a 'centralized business- and science-oriented service industry'. ${ }^{119}$ 
The ambition to turn hospitals into innovative institutions where patients could be treated with state-of-the art machinery and therapies incited the departure of hospitals from urban centres. The construction of modern hospitals in rural or suburban areas was part of a larger international trend. Hospitals were built in the proximity of cities and arterial roads (which allowed patients from rural areas to travel to the hospital by car) on open domains with enough acreage to allow for future expansions. ${ }^{120}$ In Belgium, this trend was notably followed in university towns, where researchers and physicians from the (expanding) medical faculties wished to combine patient treatment with clinical research and education. In Ghent, a new academic hospital was planned on the outskirts of town during the interwar years. In Liège, an academic hospital was inaugurated in 1985 on the site of Sart-Tilman. ${ }^{121}$ In 1975, Gasthuisberg, a new academic hospital, had opened its doors to the public in Leuven. Architecturally, these new and vast institutions consisted of a combination of several multistoreyed 'blocks'.

The continuing use of 'blocks' was encouraged by the ambitious plan to create medical centres the size of a small village. Each of these hospitals had to be built in several 'phases', which gave the impression that hospitals were located on permanent construction sites. Outsiders often perceived these large-scale institutions as labyrinths. ${ }^{122}$ Colour-coded lines on the floor served as Ariadne's thread, helping staff, visitors and patients to navigate the maze of hallways and buildings. These huge projects and their daily upkeep, however, often led to financial and management crises. The hospitals in Ghent, Leuven and Liège all had to go through a severe financial reconstruction process in the 1980s and 1990s. This also resulted in a more autonomous governance of these institutions (whereby affiliated universities saw their influence on the management of their hospitals reduced). Due to their size and the development of increasingly complex medical technologies, late twentieth-century hospitals demanded a new form of management, closer to that of business structures. ${ }^{123}$

In the last decades of the twentieth century, regard for the comfort of patients, too, pointed to the new standing of hospital medicine. Locked cupboards or the private space of one's own hospital room guaranteed patient privacy. Bedside tables were no longer regularly subjected to the intrusive control of physicians and wardens. They had become small 'command centres', adorned with switches and 
displaying phones, remote controls, radios and individual lamps. Their function was now to satisfy the patient's recognised needs and rights to comfort and entertainment.

\section{Conclusion}

The planning, building and furnishing of a hospital is no small venture. The process requires considerable investments of time and money (a substantial part of it public) and, because hospitals must sustain the health of entire populations and came to symbolise a particular form of national achievement, it demands expertise at the forefront of scientific progress. Throughout the nineteenth and twentieth centuries, Belgian officials, architects, hospital administrators, physicians and nurses have known that they could not work in isolation. Despite its occasional protectionist tendencies, Belgium - a somewhat peripheral centre of medical progress - has always sought inspiration, expertise and help from the outside. Its agents organised research visits to French, Dutch, German, Scottish, Austrian, British and then later American facilities. They took part in international networks, made good use of international medical and architectural treaties (while trying to publish a few themselves); they sought foreign investments. As a consequence, the material history of Belgian healthcare institutions can be said to follow, in its broad outline, that of most other Western countries. Nonetheless, a certain degree of conservatism (noticeable in the late implementation of most new international trends) can be pointed out, partially due to lack of funds or religious leadership (even if the latter has shown far less resistance to scientific progress than is commonly expected).

It must be stressed, however, that the history of hospital and asylum building is international in nature. One reason for this is that it had to follow closely the rapidly evolving medical and architectural sciences, themselves the product of a constant transnational dialogue. Belgium and its neighbouring countries underwent similar processes of medicalisation and, later, deinstitutionalisation and therefore had similar architectural needs. Another reason still, has to do with nonscientific transformations. In this chapter, mutations of the material environment are shown to be driven not only by scientific progress 
and technological innovations, but also by broader social changes, as well as economic, religious, aesthetic and practical motives. Many of these developments - the slow processes of secularisation and social levelling, periods of economic depression, the advent of various aesthetic and architectural movements, etc. - impacted the materiality of the whole Western world. From pavilion hospitals, to block hospitals, to huge academic hospitals; from pavilion asylums to small late-century psychiatric units; from wooden floor and furniture to enamel, iron and glass environments; from wards with heavy religious adornments to stripped-down individual rooms, the evolution of Belgian medical institutions is in no way unique.

Some of the specificities of the Belgian case, however, should not be overlooked. The persistence of religious objects and of religious spaces inside Belgian hospitals and asylums points, for instance, to the long-standing influence of the Catholic Church in both private and public healthcare, and hints at the active role Belgian patients played in the perpetuation of this situation. The Superior Health Council also acted as a distinctively Belgian unifying force. From the mid nineteenth century on, the council sought to standardise, through the setting of national norms, the architecture and materiality of many institutions. In another area, Belgium even positioned itself as a pioneer. During the last decades of the twentieth century, the process of deinstitutionalisation signalled the loosening of the imperative of patient control that had defined most of the history of medical institutions up to that point. In Belgium, the physical opening of the institutional space and the movement towards community care had a rare precedent in Gheel's colonie d'aliénés. Throughout the nineteenth and twentieth centuries, Gheel embodied an internationally appealing alternative to confining institutional care, although a study of the colony's facilities shows a history not entirely free of medical authoritarianism.

By questioning the form, function, use and meaning of spaces and objects, material history challenges the two important narratives that have defined the way historians think about hospitals and asylums: the narrative of teleological medical progress and that of social control. A focus on materiality not only offers a different perspective, but it also makes room for historical actors often overlooked by traditional historiography (patients, nurses, administrators, architects and manufacturers, etc.). It shines 
a light on a multiplicity of points of view and, by doing so, nuances accounts of power dynamics and overly simplistic analyses of the individual and collective motivations propelling changes.

Today, much is left to explore about the materiality of Belgian hospitals and asylums. The manufacture of medical equipment and of institutional furniture, hospital construction companies, medical imagery, patient material culture, etc., are only some of the areas of institutional material culture about which historians of Belgium are still ignorant. The history of medicine in Belgium in its entirety, too, is still many steps away from its 'material turn'. Most of its subfields of research could undoubtedly benefit from a new material approach.

\section{Notes}

1 See, among others, archives from the Centre public d'action social of Bruxelles (hereafter ACPASB), St-Jean Hospital fonds, registres des surveillants, 3 and 4.

2 A. Appaduraj (ed.), The Social Life of Things: Commodities in Cultural Perspective (Cambridge, UK: Cambridge University Press, 1986).

3 J. D. Prown, 'The truth of material culture: history or fiction?', in History from Things: Essays on Material Culture, ed. S. Lubar and D. W. Kingrey (Washington, DC: Smithsonian Institution Press, 1993), 2-3.

4 Ibid., 1.

5 J. Hamlett, At Home in the Institution: Material Life in Asylums, Lodging Houses and Schools in Victorian and Edwardian England (Basingstoke: Palgrave Macmillan, 2015).

6 G. Adamson, 'The case of the missing footstool: reading the absent object', in History and Material Culture: A Student's Guide to Approaching Alternative Sources, ed. K. Harvey (London: Routledge, 2009), 192-217.

7 For example, P. Allegaert et al. (eds), L'architecture hospitalière en Belgique (Brussels: Ministère de la Communauté flamande Monuments et Sites, 2005); L'espace de vie du malade à l'hôpital, exposition au C. H. U. André Vésale à Montigny-le-Tilleul, 17 October-11 November (Association belge des hôpitaux, 1990).

8 This association is still active today under the name Hospitium.

9 B. Majerus, 'Material objects in twentieth century history of psychiatry', BMGN: Low Countries Historical Review, 132:1 (2017), 
149-69; S. Richelle, Hospices. Une histoire sensible de la vieillesse. Bruxelles, 1830-1914 (Rennes: Presses universitaires de Rennes, 2019).

10 A. Adams, Medicine by Design: The Architect and the Modern Hospital, 1893-1943 (Minneapolis: University of Minnesota Press, 2008), xxv.

11 B. Wall, Unlikely Entrepreneurs: Catholic Sisters and the Hospital Marketplace, 1865-1925 (Columbus: Ohio State University Press, 2005), 121.

12 C. Dickstein-Bernard, 'L'initiative communale en matière hospitalière entre 1795 et 1940', in L'initiative publique des communes en Belgique 1795-1940, I, 12 eolloque international de Spa, 4-7 September 1984 (Brussels: Crédit Communal, 1986), 375-404.

13 T. Markus, Buildings and Power: Freedom and Control in the Origin of Modern Building Types (London: Routledge, 1993).

14 This was a general complaint of medical professionals all over Europe. See G. B. Risse, Mending Bodies, Saving Souls: A History of Hospitals (Oxford: Oxford University Press, 1999).

$15 \mathrm{~J}$. Reinarz, 'Learning to use their senses: visitors to voluntary hospitals in eighteenth-century England', Journal for Eighteenth-Century Studies, 35:4 (2012), 509.

16 A. Corbin, The Foul and the Fragrant: Odor and the French Social Imagination (Cambridge, MA: Harvard University Press, 1986).

17 J. Guislain, Leçons orales sur les phrénopathies, ou traité théorique et pratique des maladies mentales, vol. 3 (Ghent: Vanderhaeghen, 1852), 344.

18 L. Wellens-De Donder, 'Enquête sur les hôpitaux d'Europe occidentale en vue de la construction et de l'agencement du nouvel hôpital SaintJean à Bruxelles 1828-1830', Annales de la Société Belge d'Histoire des Hôpitaux/Annalen van de Belgische Vereniging voor HospitaalGeschiedenis (ASBHH/ABVGH), 8 (1970), 111.

19 See the Royal Navy Hospital (opened in 1762) near Plymouth, England, or l'hôpital de la Marine (1788) in Rochefort, France.

20 D. Vandevijver, 'Vers une architecture qui soigne: construction d'hôpitaux à pavillons en Belgique au 19ème siècle (1780-1914)' in Allegaert et al., L'architecture hospitalière en Belgique, 59.

21 A. Uytterhoeven, Notice sur l'hôpital de Saint-Jean de Bruxelles (Brussels: Gregoir, 1852), vi.

22 Conseil supérieur d'hygiène publique, Instruction pour la construction et l'arrangement intérieur des hôpitaux et hospices (Brussels: De Mortier, 1853).

23 E. Bruyneel, De Hoge Gezondheidsraad (1849-2009). Schakel tussen wetenschap en volksgezondheid (Leuven: Peeters, 2009), 51-54. 
24 'Agentschap Onroerend Erfgoed 2020: Stuivenberg', https://id.erfgoed. net/erfgoedobjecten/7112 (accessed 14 March 2020).

25 M. Beets-Anthonissen, 'Anvers. Hôpital Stuyvenberg' in Allegaert et al., L'architecture hospitalière en Belgique, 96-7.

26 Vandevijver, 'Vers une architecture qui soigne', 60.

27 ACPASB, Affaires Générales du Conseil (hereafter AGC), C394, fo. 'Fleurs, plantations'.

28 'Ordonnances concernant l'exercice de l'art de guérir en Autriche', Gazette médicale belge, 3 (1845), 219.

29 T. Claes and P. Huistra, "Il importe d'établir une distinction entre la dissection et l'autopsie". Lijken en medische disciplinevorming in laatnegentiende-eeuws België', BMGN: Low Countries Historical Review, 131:3 (2016), 26-53.

30 C. Crommelinck, Rapport sur les hospices d'aliénés de l'Angleterre, de la France, et de l'Allemagne (Kortrijk: Jaspin, 1842), 10.

31 P. Allegaert et al., Ziek tussen lichaam en geest / Malade entre corps et esprit (Lannoo: Tielt, 2007), 21-2.

32 E. Langendries and A. van der Meersch, Het Rommelaere complex: onderdeel van het gebouwenmasterplan voor de Gentse univerisiteit op het einde van de 19de eeuw (Ghent: Archief RUG, 1999), 43-57.

33 'Maison d'aliénés pour hommes', Le Messager de Gand (31 October 1856).

34 S. Richelle, 'Hospices: lieux et expériences de vieillesses. Bruxelles, 1830-1914' (PhD diss., University of Luxembourg, 2017), 262-3.

35 'Les institutions médicales de Bruxelles', Gazette médicale belge 3 (10 January 1845), 11.

36 ACPASB, AGC, 126, fo. 'Le complément de mobilier - quartier des malades en construction, 1863 '.

37 Uytterhoeven, Notice, 99.

38 On the organisational aspect of family care, see K. Veraghtert, 'Naar een moderne gezinsverpleging te Geel (1730-1860)', ASBHH/ ABVGH, 8 (1970), 55-73.

39 B. De Meulder, 'Het Dr. Guislaininstituut in het reformistisch architectuurlandschap. Nota's bij het ontstaan van de Gentse modelinstelling', in Rede en waanzin: het museum Dr. Guislain in beeld en tekst, ed. P. Allegaert and A. Cailleu (Ghent: Museum Dr. Guislain, 2001), 313.

40 J. Moran and L. Topp, 'Introduction', in Madness, Architecture and the Built Environment, ed. J. Moran, L. Topp and J. Andrews (New York: Routledge, 2007), 2-4.

41 D. Jaenen, 'Ouvrez les portes! Contacten tussen patiënten en 'bezoekers' in het Guislaininstituut (1857-1914)' (master's thesis, Katholieke Universiteit Leuven, 2016). 
42 'Société de Médecine Mentale de Belgique: procès-verbal de la séance extraordinaire tenue à Gheel le 19 et 20 juillet 1875', Bulletin de la Société de Médecine mentale de Belgique, 6 (1875), 22.

43 W. Parry-Jones, 'The model of the Geel Lunatic colony and its influence on the nineteenth-century asylum system in Britain', in Madhouses, Mad-Doctors, and Madmen: The Social History of Psychiatry in the Victorian Era, ed. A. Scull (Philadelphia: University of Pennsylvania Press, 1981), 201-17; A. Fauvel, 'Les fous en liberté. La naissance des “colonies familiales” de la Seine', Revue de la Société française d'histoire des hôpitaux, 136 (2010), 16-22; A. Hushimoto, 'The invention of a "Japanese Gheel": psychiatric family care from a historical and transnational perspective', in Transnational Psychiatries: Social and Cultural Histories of Psychiatry in Comparative Perspective c. 1800-2000, ed. W. Ernst and T. Muller (Newcastle: Cambridge Scholars, 2010), 142-72.

44 Ministère de l'Intérieur et de l'Hygiène, Instruction concernant les projets d'hôpitaux et d'hospices à construire en matériaux légers. Rapport du Conseil Supérieur d'Hygiène Publique (Brussels: Ministère de l'Intérieur, 1928).

45 A. Depage, P. Vandervelde and V. Cheval, La construction des hôpitaux. Etude critique (Brussels: Misch \& Thron, 1912), 116-67.

46 Ibid., 147-8.

47 Ibid., 122-3.

48 B. Mihail, 'L'hôpital militaire d'Ixelles. De fleuron de l'hygiénisme à chancre urbain', Les Cahiers de la Fonderie, 52 (2017), 18; C. Heusquin, 'L'hôpital Brugmann de l'Assistance Publique de Bruxelles', L'Assistance Hospitalière, 2 (1930), 57; G. Maukels, 'Hôpital Français Reine Élisabeth', L'Assistance Hospitalière, 3 (1931), 134.

49 See, for instance, A. Joiris, 'Le vieux Bavière au XIXe siècle, 18301895', ASBHH/ABVGH, 20 (1982), 112-23.

50 Heusquin, 'L'hôpital Brugmann', 51-91.

51 A. Bouchet, 'Histoire de la construction de l'hôpital Edouard-Herriot de Lyon', Histoire des sciences médicales, XX (1986), 91-2.

52 Antisepsis was introduced in the early 1880s in Brussels and in the 1890s in Liège, see C. Dickstein-Bernard, 'La pratique de la chirurgie dans les hôpitaux bruxellois au XIXe siècle', ASBHH/ABVGH, 19 (1981), 89-94; Joiris, 'Le vieux Bavière', 125-6.

53 Conseil supérieur d'hygiène publique, Instruction pour la construction, 8-9.

54 Depage et al., La construction des hôpitaux, 143-5; Heusquin, 'L'hôpital Brugmann', 58.

55 As was the case in the old Liège public hospital before the 1890s, see Joiris, 'Le vieux Bavière', 117. 
56 Ministère de l'Intérieur et de l'Hygiène, Instruction, 10.

57 Ibid., 10-11; ACPASB, Affaires Générales Médicales, Personnel Médical, Chefs de service, Réunions 1899-1912, 6, rapports de la Société des Chefs de service, Rapport sur la désinfection par R. Verhoogen, 1-2.

58 Depage et al., La construction des hôpitaux, 140.

59 Ministère de l'Intérieur et de l'Hygiène, Instruction, 19.

60 Verhoogen, Rapport sur la désinfection, 2.

61 Ibid.

62 Ibid., 2-3.

63 A. Roekens (ed.), Des murs et des femmes. Cent ans de psychiatrie et d'espoir au Beau-Vallon (Namur: Presse Universitaire de Namur, 2014), 40.

64 Van de Vijver, 'Vers une architecture qui soigne', 63.

65 Conseil supérieur d'hygiène publique, Instruction, 8; Administration du service de santé et de l'hygiène du Ministère de l'Intérieur, Instruction adoptée par le Conseil supérieur d'bygiène publique le 1er juin 1911 concernant les projets d'hôpitaux et d'hospices (Brussels, 1911), 11.

66 Maukels, 'Hôpital Français Reine Élisabeth', 135.

67 Heusquin, 'L'hôpital Brugmann', 59-60.

68 B. Majerus, Parmi les fous: Une histoire sociale de la psychiatrie an XXe siècle (Rennes: Presse Universitaire de Rennes, 2013), 50-51.

69 Depage et al., La construction des hôpitaux, 163.

70 A. Goossens-Bara, 'De l'admission des malades payants dans les Hôpitaux des Commissions d'Assistance Publique', L'Assistance Hospitalière, 2 (1932), 55.

71 P. Bonenfant, 'Note historique', L'Assistance Hospitalière, 2 (1932), 63.

72 Goossens-Bara, 'De l'admission', 56.

73 Ibid., 56.

74 Roekens, Des murs et des femmes, 39-40.

75 V. Leclercq, 'Guérir, travailler, désobéir: une histoire des interactions hospitalières avant l'ère du patient autonome (Brussels, 1870-1930)' (PhD diss., Université Libre de Bruxelles, 2017), 105-8.

76 Joiris, 'Le vieux Bavière', 115.

77 Ibid.

78 On the prostitute quarters in St-Pierre, see De Ganck, 'Cultiver la différence. Histoire du développement de la gynécologie à Bruxelles (1870-1935)' (PhD diss., Université Libre de Bruxelles, 2015), 189-201.

79 ACPASB, Papers of the director of the St-Pierre Hospital (hereafter PDHSP), soins aux malades, fo.251, table 'répartition des salles' 
(30 January 1914), letter from Dr Bayet to the Conseil Général, 4 November 1905.

80 ACPASB, AGC, 132, fo. 'la plainte des nommées R. \& R. à charge de M. le directeur de l'hôpital Saint Pierre', letter from Isabelle R. and Jeanne R. to the Public Prosecutor, 1 February 1892.

81 Leclercq, 'Guérir, travailler, désobéir', 79.

82 Ibid., 270.

83 Richelle, 'Hospices', 138.

84 N. Ghijs et al. (eds), Het Onze-Lieve-Vrouwehospitaal te Oudenaarde en de zusters Bernardinnen: Een bijdrage tot de ontsluiting van 800 jaar geschiedenis, 1202-2002 (Ghent: Provinciebestuur OostVlaanderen, 2004), 175.

85 Roekens, Des murs et des femmes, 41.

86 W.-H. Mansholt, 'Openbare en particuliere Ziekenhuizen', L'Assistance Hospitalière, 6 (1929), 271.

87 In 1908, 97.3 per cent of the patient population of Brussels public hospitals still identified as Catholic, see Administration des Hospices et Secours de la Ville de Bruxelles, Comptes moraux de l'Administration des Hospices et Secours de la Ville de Bruxelles (Brussels: Administration des Hospices et Secours de la Ville de Bruxelle, 1908).

88 See the St-Jean Hospital, the Charleroi Municipal Hospital or the Stuyvenberg Hospital: ACPASB, fonds iconographique, série H/ H.ST-J./8: 'Plans et vues principales de l'Hopital St-Jean à Bruxelles' (1863), 1; Depage et al., La construction des hôpitaux, 437; Beets-Anthonissen, 'Anvers, Hôpital Stuyvenberg', 96.

89 Leclercq, 'Guérir, travailler, désobéir', 274-87.

90 ACPASB, FDHSP, fo. 317, letter from Léonie S. to 'Monsieur le Directeur', c.1886.

91 Richelle, 'Hospices', 145.

92 Leclercq, 'Guérir, travailler, désobéir', 284-5.

93 C. M. Mangion, " "To console, to nurse, to prepare for eternity”: the Catholic sickroom in late nineteenth-century', Women's History Review, 24:4 (2012), 662.

94 Bruyneel, Hoge Gezondheidsraad, 200.

95 Set up in record time inside the Hotel de l'Océan, the 'ocean hospital' in La Panne treated wounded soldiers sent back to the coast from the Yser Front. See R. Redin, L’hôpital de l'océan. La Panne 1914-1919. Une aventure belge au cour de la tourmente (Brussels: Les Editions Jourdan, 2014).

96 About the construction of the new St-Pierre Hospital and the Rockefeller Foundation, see D. Guilardian, 'Saint-Pierre \& Bordet: de l'art déco 
au modernisme', in Du monumental au fonctionnel: l'architecture des hôpitaux publics bruxellois (XIXe-XXe siècles), ed. A. Lelarge et al. (Brussels: Éditions CIVA, 2005), 75-96.

97 J.-M. Wydooghe, 'Le Nouvel Hôpital Universitaire Saint-Pierre, à Bruxelles', L'Assistance Hospitalière, 1 (1930), 11.

98 Guilardian, 'Saint-Pierre \& Bordet', 79-81.

99 About the layout of the new St-Pierre Hospital, see Wydooghe, 'Le Nouvel Hôpital Universitaire Saint-Pierre', 11-31; Guilardian, 'SaintPierre \& Bordet', 95.

100 'Rapports des Commissions et des Sous-Commissions: Conditions relatives aux salles qui sont nécessaires pour les soins aux malades (IIIe Congrès International des Hôpitaux, Knocke-sur-Mer)', L'Assistance Hospitalière, 2 (1933), 57-8, 67.

101 S. Dehaeck and R. van Hee, 'De l'hospice à l'hôpital virtuel?' in Allegaert et al., L'architecture hospitalière en Belgique, 22.

102 Bruyneel, Hoge Gezondheidsraad, 199.

103 P. Depage, 'Le Centre de diagnostic dans les Hôpitaux', L'Assistance Hospitalière, 6 (1929), 291.

104 C. Reinmann, 'Quelques observations sur le nombre d'Infirmières en fonction du nombre de malades', L'Assistance Hospitalière, 3 (1931), 191.

105 Bruyneel, Hoge Gezondheidsraad, 199.

106 About modernist architecture in Belgium and the influence of the Brunfaut family on the architectural landscape of Brussels and Flanders, see J.-M. Basyn et al. (eds), Brunfaut's progressive architecture (Brussels: CFC Editions, 2013).

107 F. Héger-Gilbert, Déontologie Médicale (Brussels: Maison Ferd. Larcier, 1946), 100-1.

108 J.-M. Wydooghe, 'Les Annexes indispensables d'une Salle de malades', L'Assistance Hospitalière, 1 (1933), 19.

109 Wydooghe, 'Le Nouvel Hôpital Universitaire Saint-Pierre', 21-2.

110 Basyn, 'Hôpital de l'entre-deux-guerres', 66.

111 M. Carlier, 'La genèse de l'assurance maladie-invalidité obligatoire en Belgique', Courrier hebdomadaire du CRISP, 7:872-3 (1980), 36.

112 Beets-Anthonissen, 'Anvers. Hôpital Stuyvenberg', 99.

113 Ministère de la santé publique et de l'environnement, 30 ans de la loi sur les hôpitaux en Belgique (n.pub., 1994), 14.

114 For a deeper analysis of the subject in the US context, see N. Tomes, 'Merchants of health: medicine and consumer culture in the United States, 1900-1940', Journal of American History, 88:2 (2001), 519-47.

115 L'espace de vie du malade, 19.

116 Roekens, Des murs et des femmes, 169-74. 
117 Beets-Anthonissen, 'Anvers. Hôpital Stuyvenberg', 98.

118 This was the case for the new St-Pierre Hospital and in Brugmann Hospital.

119 This was also an international development, see, for example, D. Theodore, S. D. Burke and A. Adams, 'Tower of power: the Drummond medical building and the interwar centralization of medical practice', Medical Science and Medical Buildings, 32/1 (2009), 51-68.

120 F. Danniau, 'Naar een Academisch Ziekenhuis', UGentMemorie, www.ugentmemorie.be/artikel/naar-een-academisch-ziekenhuis (accessed 14 March 2020); G. Deneckere, Uit de Ivoren Toren. 200 jaar universiteit Gent (Ghent: Tijdsbeeld, 2017), 134-8.

121 G. Schoefs, F. Lorant and P. Henrion, La leçon d'anatomie. 500 and de médecine à Liège (Liège: Now Future, 2017).

122 J. Tollebeek and L. Nys, De stad op de berg: een geschiedenis van de Leuvense universiteit sinds 1968 (Leuven: Leuven University Press, $2005), 153$.

123 L. Nys, Van mensen en muizen. Vijftig jaar Nederlandstalige faculteit geneeskunde aan de Leuvense universiteit (Leuven: Leuven University Press, 2016), 159-63.

\section{Selected bibliography}

Allegaert, P. et al. (eds), L'architecture hospitalière en Belgique/Architectuur van de Belgische hospitalen (Brussels: Ministerie van de Vlaamse Gemeenschap. Afdeling Monumenten en Landschappen, 2004).

Appaduraj, A. (ed.), The Social Life of Things: Commodities in Cultural Perspective (Cambridge, UK: Cambridge University Press, 1986).

Bruyneel, E., De Hoge Gezondheidsraad (1849-2009). Schakel tussen wetenschap en volksgezondheid (Leuven: Peeters, 2009).

Deblon, V., 'Constructing the illusion of freedom: architecture and psychiatry in nineteenth-century Belgium', Journal of Belgian History, 47 (2017), 84-11.

Hamlett, J., At Home in the Institution: Material Life in Asylums, Lodging Houses and Schools in Victorian and Edwardian England (Basingstoke: Palgrave Macmillan, 2015).

Henderson, J., Horden, P. and Pastore, A. (eds), The Impact of Hospitals 300-2000 (Oxford: Peter Lang, 2007).

Lelarge, A., Dickstein-Bernard, C., Guilardian, D. and Le Maire, J. (eds), Du monumental au fonctionnel: l'architecture des hôpitaux publics bruxellois (XIX ${ }^{e}-X X^{e}$ siècles) (Brussels: Editions CIVA, 2005). 
L'espace de vie du malade à l'hôpital, exhibition at C. H. U. André Vésale à Montigny-le-Tilleul, 17 October-11 November 1990 (Brussels: Association belge des hôpitaux, 1990).

Majerus, B., 'Material objects in twentieth century history of psychiatry', BMGN: Low Countries Historical Review, 132:1 (2017), 149-69.

Richelle, S., Hospices. Une histoire sensible de la vieillesse. Bruxelles, 1830-1914 (Rennes: Presses Universitaires de Rennes, 2019). 